\title{
INCREASING PALINKA RECOGNITION WITH TOURISM AND GASTRONOMY
}

\author{
Imre Milan Harcsa \\ University of Debrecen, Faculty of Economics and Business \\ harcsa.i.milan@gmail.com
}

\begin{abstract}
The history of Hungarian palinka distillation dates back thousands of years. Palinka is a special product; its quality features are being increasingly recognized and appreciated by consumers. Our national drink went through considerable transformations in the past years, as it left the village environment behind and has become a Hungaricum, popular with young people. The authorization of home distilling in September 2010 was a key factor in its gaining ground in the country. In connection with this topic, the international practice of beverage tourism has been reviewed. After that, the Hungarian practice was examined, including the selection of palinka festivals, thematic palinka tours and palinka product ranges in 19 counties and in Budapest based on a total of 100 restaurants. Using SWOT analysis I revealed the strengths, weaknesses, opportunities and threats of palinka gastronomy and pálinka industry. Overall, it was found that the popularity of pálinka is increasing, but the thematic pálinka tours have not yet widened, and there is a need for more procedures supported by community marketing.
\end{abstract}

Keywords: palinka tourism, tours and festivals, burgeon of palinka sortiment (JEL Code: Z30, E83)

\section{INTRODUCTION}

Increased globalization resulted in the recognition and promotion of values and traditions have become significant for each nation. Palinka is a Hungarian national treasure, which is to be preserved and cultivated. Over the last ten years palinka has come a long way, it has left behind its limited context of 'peasants' drink, and it has become our favourite national drink and treasure. Agricultural Marketing Centrum has been a key player in this process since it provided an increasing amount of resources for the popularization of palinka, palinka culture, and civilized palinka consumption. Also, focus on quality by manufacturers, their efforts, expertise, and cooperation were also the requirements of achieving the above mentioned. This process was also facilitated by the abolition of the excise tax of subcontract distillation and the authorization of home distilling (up to the volume of 43 hectolitre degree is equivalent of 86 litre 50 volume percent of distillate). Palinka festivals and fairs are organized in various parts of the country, and several palinka songs have already been created. "The number of expert distilleries is increasing, new palinka houses are opened, palinka tastings and palinka festivals are staged. Palinka has its saint (Saint Michael, 6th December); it has its town, the order of knights and even palinka sanctification has already taken place in the Franciscan church in Miskolc" (Balazs, 2012). Palinka has grown up to become the counterpart of other national drinks both in its quality and price. The present study seeks to present the new and potential avenues to promote civilized palinka consumption, in particular, opportunities provided by tourism and gastronomy. The web page maintained by Hungarian Tourism Agency lists merely 20 results if places for palinka tasting are searched for. (I1) In contrast, the number of search results surges to 80 or above 100 (the dominant value) if Austrian, German or French tasting places are looked for. According to my hypothesis, the recognition of Hungaricum palinka widely known mostly in Hungary can be promoted by special means provided by tourism and gastronomy.

\section{MATERIAL AND METHODS}

As I work in a family business engaged in palinka subcontract distillation, I personally experience the impact of the changes of the legislative environment exerted on enterprises; in this way, I am capable of monitoring the direct feedback of subcontract distillers' clients. The study is primarily based on secondary research. Information was collected on international alcohol tourism through literatute rewievs and then it was described the Hungarian practice. A short introduction was given of the system of home distilling institutions and its effect on the improvement of quality. It was carried out the related SWOT analysis, where examined the strengths, weaknesses, opportunities and threats of palinka gastronomy and palinka industry. In addition it was made a 
survey where the popularity of palinka in certain restaurant and catering facilities was measured.

\section{RESULTS \\ International practice}

The cognac route called "Etapes du cognac" offers three paths along the river Charente, where the secrets of cognac preparation and still used ancient methods can be discovered. Those interested are offered one-day, one-weekend or oneweek long program packages. (I2)

Genuss Region Marketing, of which loose translation is "a marketing office for a gourmet region" is prospering in Austria. Certain regions have been classified into various categories in terms of specific and outstanding specialities and they were labelled as "gourmet" regions. In Austria 116 regions have been granted the honorary title of the gourmet region due to certain special dishes or products. The "Austrian gourmet region" title can merely be awarded to regions which take pride in their outstandingly high-level regional specialties. The "office" seeks to coordinate the numerous gourmet regions, support them with marketing materials, collect sponsors, stage venues and sell the products prepared in the region through web shops. It is in cooperation with the local ministry of the food industry and provides potential opportunities for them to introduce their products and activities in foreign countries. (I3) One of these regions is Ober-Grafendorf, where the cornel festival called "Pielachtaler Dirndlkirtag" is organized in October on an annual basis. Peter Aradi, palinka master, founder of the "Cornel Association" claims that interested people get an opportunity to visit a well-organised exhibition and fair that offers jewellery, buttons, cosmetic products, jams, mustard, syrups, liquors, chocolate, desserts, various dishes and naturally, distillates made of cornel. They can also take part in walking tours in the town and nearby plantations stretching for $5 \mathrm{~km}$. It is enriched by a machine exhibition, a competition of various distillates, music and dance programs.

A catering industrial complex in Germany is similarly focusing on a specific fruit, i.e. strawberry. The fact that accommodations and playgrounds with programs for children are available in the vicinity of the plant indicates that progress has been made, and the products can be purchased online as well. (I4)

\section{Situation in Hungary}

Geza Balazs, linguist and ethnographer used the expression "palinka tourism" back in 2008. In his Ph.D. thesis Laszlo Kopcsay used this notion likewise in the same year, but mentioned it as "a not-yet-existing potential market attraction”. Edit Szollosi, palinka master, claimed in 2016 that we could not talk about well-organized palinka tourism, only separate, isolated initiatives. The authors agree that specifically in those regions, those areas have a reasonable chance to create palinka tourism where traditional alcohol culture is closely linked to palinka consumption. What is the meaning of the expression? Building on the precedent set by the existing and often quoted wine tourism, palinka tourism is classified as a branch of agritourism, where the agricultural source material is represented by fruits (or marc) and the food industrial plant by the palinka distillery, the product is the palinka manufactured and stored on the spot, whereas these products are introduced in palinka tasting venues.

\section{Authorization of home distillation - improvement of quality}

Kopcsay (2008, 88.p.) in his doctoral dissertation discussed the situation of Hungarian palinka as follows: "The greatest threat for palinka is still posed by the black market. Clearly, even if it sparks conflicts, it must be stated that at present, subcontract distilleries and gastronomy hinder the sale and credibility improvement of high-quality palinka. The Hungarian government could be a potential partner in finding a solution for this issue..." Private distillers suffer from the same accusations on multiple occasions: they are said to produce millions of litres of palinka at home, without control.

The present government of Hungary pledged to grant the right of free palinka distillation again in the previous election campaign. As of 27 September 2010 the practice of the previously not available home palinka distillation was introduced. Home distillers are natural persons above 18 years who prepare distillates from raw materials from their own orchards by using their own distilling equipment. In the case of home distillation or subcontract distillation, the end product is distillate, whereas the end product in a commercial distillery is labelled palinka, although the base materials, the process of production and the applied technologies are the same. The distinction was required for the protection of Hungarikum palinka. (Harcsa, 2016)

Naturally, good and poor quality products are equally produced in commercial practice, home distillation and subcontract distillation. However, since the legalisation of home distillation the most excellent experts and academic professors in the country have substantially contributed to spreading the know-how of palinka preparation.

A number of NQR (National Qualifications Register) trainings launched at the Faculty of Food Industry, Corvinus University, Hungary and Palinka master training courses (providing students with BSc qualification) are worth mentioning. Post-graduate technical training courses are also offered for students by well-renowned palinka experts.

It must be noted that the first Hungarian "palinka agency", engaged in the organization of palinka tours, competitions, professional programs, trainings, was established by the graduates of the first year to boost the further development of palinka, our national treasure.

Since home distillers have been able to participate in competitions with their products, the quality of their palinka is increasing year by year in the practice of home distillers and on commercial level likewise.

Two registered home distillers and their results are the following: 
Pálinkárium, Gyenesei - István Gyenesei - prolific Hungarian, European and world champion of palinka preparation.

Pavlinkárium - Csaba Pavlicsek - the best home distiller in Hungary (2014), medal winner at world and European palinka preparation championships

\section{Palinka festivals, palinka tourism}

Tourism should rely on thematic palinka tours and festivals as equal, complementary elements of a single system providing an attraction for customers. (Michalko, 2007) In Hungary palinka tourism is not yet fully organized, although several initiatives have emerged, which must be strengthened and developed. They may be realized in rural areas where large-scale fruit production is carried out and the key element of traditional alcohol culture is palinka, but several other products are also available. To achieve this goal, high-level additional programs will be required.

"Festivals can be defined as a series of regular venues structured around one or several topics on one or multiple sites with programs dedicated to culture, art, gastronomy, sport or other issues that seek to provide their audience with outstandingly high level, entertaining recreation experience by transmitting values and spreading information." (Hungarian Festival Association)

Sandor Lovasz organized the first palinka festival in Gyula in 2000. He discusses how the original idea was put into practice in one of the chapters of the book "Good Hungarian palinka”. (Dlusztus and Soos, 2014) Since then the festival has taken on an international dimension, its programs offer palinka and distillate competitions and various other initiatives follow its footsteps to promote palinka consumption. Examples are the "Debreczen Palinka and Sausage Festival or the free palinka day celebrating "home made" palinka in Zemplen.

Festivals are important for consumers, as they can find the whole range of products manufactured by multiple producers on one site at a given date. This is relevant, as the product range comprises innumerable tastes and odours in excess to the basic ones. One might build up a totally different picture of palinka: it is not merely a prickly, smelly, unpleasant drink, but also a treat full of fruits with pleasant odour and taste. "Certain festival seasons aim at imparting information. Not customer recruitment. The ultimate goal is to raise the awareness of a lot of people that palinka is a tasty drink and to maintain permanent interest in it. If this succeeds, people will be eager to get information about it. This is the starting point of training new customers and this is different from urging people to booze. Very different! This is the moment of developing a taste for this premium category drink and praising its high quality. The acknowledgement of the Hungarian national drink" (Guth, 2008)

The Bekesi Plum Palinka Path crosses three settlements: Bekes, Bekescsaba and Gyula. Bekesi Szilva is a fruit distillate bearing a protected geographical indication that can be prepared from red plum in 17 settlements in Bekes County. The Path can join the representative facilities of local gastronomy, restaurants and touristic enterprises.

Bekesi Szilvapalinka Centrum: A centre with a facility for palinka tasting with a seating capacity of 42 and a hall with a seating capacity of 80 for hosting nationwide venues in the middle of Bekes town. I personally had the chance to admire it and Figure 1. presents the photo of the building.

Figure 1. Building of the Bekesi Szilvapalinka Centrum. Source: Author's photo, 11.08. 2016.

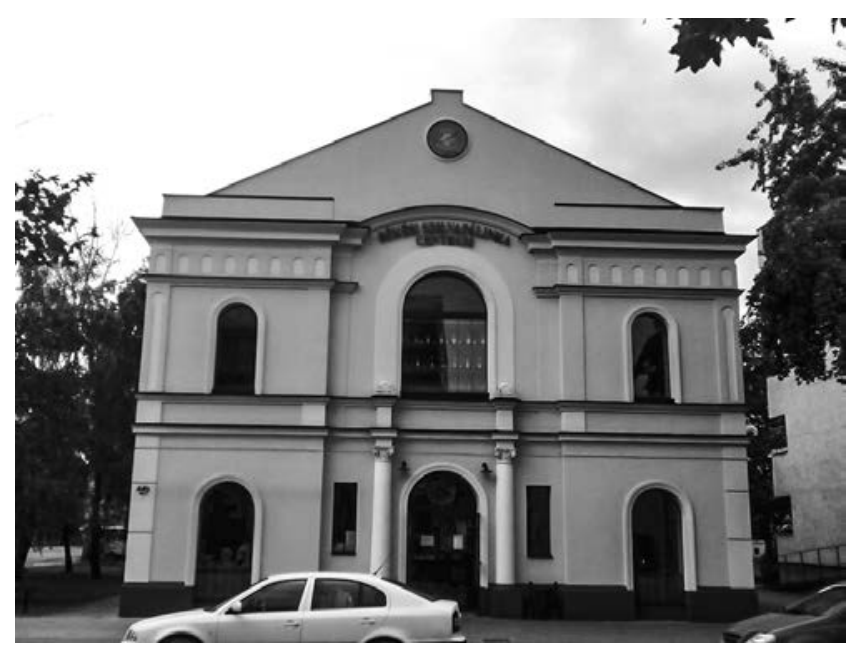

Arpad Palinka Tanya: A distilling plant in the northern part of Bekescsaba, operating for more than 10 years. Young entrepreneurs safeguard its expansion in terms of product range and services based on their knowledge and experience learnt from their fathers in the framework of the newly established Kisret Manufactory Ltd. It includes a tasting and exhibition facility with a seating capacity of 24 where they can showcase their own premium palinka products and touristic program packages.

Gyulai Palinka Tasting Facility is situated along the bypass road of Highway 44, not far from the Romanian border, in the outskirts of Gyula. It is operated by the Gyulai Palinka Manufactory Ltd. It has a facility for palinka tasting with a seating capacity of 42 where visitors can get an understanding of plum production and processing.

Bekesi Szilvapalinka Information Office: It is situated in the centre of Gyula and it is jointly operated by three enterprises through Palinkaway Ltd. It is in charge of coordination, providing information, organization and assistance for tourist groups and selling the products of three enterprises.

The Szatmar-Beregi Plum Path (Figue 2 shows it's map) is not a typical palinka path. The stops along the thematic route raise awareness of palinka as well as the preparation of plum jam and tourists can try their hands at preparing their own plum jam. In addition, they can have an insight into the process of plum drying. Figure 2. shows the map of the plum path. "The path is highly popular due to the fact that settlements attempt to revive their local and village celebrations with initiatives to enrich their programs" claimed Dr. Arpad Hanusz, Director of the Institute of Tourism and Geological Sciences, College of Nyiregyhaza. He added that 
"the services offered by the Palinka path have the required qualifications and authorizations to meet international standards" (I5)

It can be divided into three sub-sections and the programs are closely related to them:

- Small plum path (9 settlements, approximately $90 \mathrm{~km}$ ) from Penyige to Panyola

- Large plum path (16 settlements, approximately $340 \mathrm{~km}$ ) from Vasarosnameny to Vasarosnameny,

- Szatmar-Szatmar plum path (29 settlements, approximately $560 \mathrm{~km}$ ) from Vasarosnameny to Szatmarnemeti.

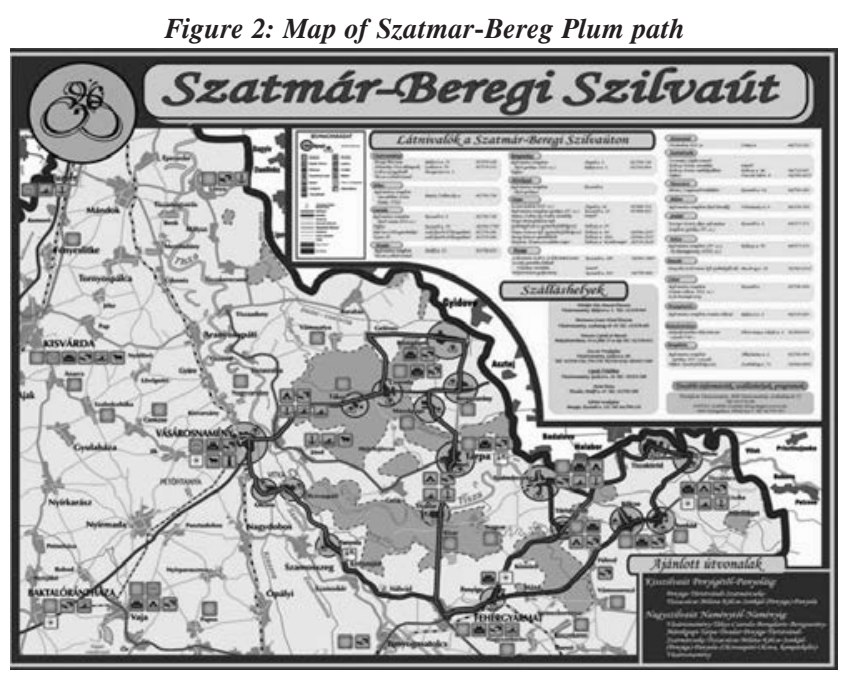

Source: (I6)

An increasing number of palinka distilleries transform themselves into enterprises representing Hungarian gastronomy, cultural events and visitor friendly plants. One particular example for this is Agard Distillery or Zsindelyes Distillery. They showcase their palinka distilling equipment, the process of palinka distillation and maturation, bottling. They also organize palinka tastings over lunch or supper.

Recently, initiatives have been launched to bring conscious consumers closer to tourism opportunities an example for this is the EU fund tendered by Tuzser Distillery, which provided the financial background for the establishment of accommodation facilities on the distillery site. At the hand-over ceremony it was emphasised that this type of initiative would be a significant contribution to disadvantaged settlements where unemployment has been posing a significant problem for long years or decades. The creation of new jobs can ensure a decent existence for those who would like to choose this profession.

Janos Komaromi, CEO stated that a hall was available for palinka tasting on the site with five fully equipped wooden houses for several people. Visitors can rest in the sauna and in a vat bath and may participate in water tours on the Tisza River. All these may give opportunities for families to spend several days with entertainment. (I-7.)

A tourism-marketing initiative has been launched to advance the recognition of not only the town, but also the palinka plant. Keresztur Palinka Manufactury, encouraged by the success of Palinka song in 2009, entered into a contract with Magna Cum Laude pop band for the right of using the name. The members of the band always take some bottles of palinka for their concerts and the audience can taste these products, mostly at low-key club events. This is the take-up activity for the Palinka song. At big festivals they set up a small stand where they can show their products to the public. This is a valuable initiative, as the band was established in Gyula, and the town is located in the area bearing a protected geographical indication for Bekes plum palinka. This is a great opportunity to advertise the town and may boost its tourism in the future.

Thematic paths, e.g. Bekes Plum Palinka Path do have their future, where foreign tourists and Hungarian people can get acquainted with palinka, the heritage of Bekes County while taking an awareness-raising tour. Table 1 . shows our comparisons with the international examples listed above.

Table 1: Comparison of drink tourism destinations

\begin{tabular}{|c|c|c|c|c|}
\hline Name & $\begin{array}{c}\text { Etapes du } \\
\text { cognac }\end{array}$ & $\begin{array}{c}\text { Ober- } \\
\text { Grafendorf }\end{array}$ & Rövershagen & $\begin{array}{l}\text { Plum } \\
\text { paths }\end{array}$ \\
\hline Tasting & $\mathrm{X}$ & $\mathrm{X}$ & $\mathrm{X}$ & $\mathrm{X}$ \\
\hline Meals & $\mathrm{X}$ & $\mathrm{X}$ & $\mathrm{X}$ & $\mathrm{X}$ \\
\hline Accommodation & $\mathrm{X}$ & $\mathrm{X}$ & $\mathrm{X}$ & $\mathrm{X}$ \\
\hline Visit To Plant & $\mathrm{X}$ & & $\mathrm{X}$ & $\mathrm{X}$ \\
\hline Souvenir Shop & $\mathrm{X}$ & $\mathrm{X}$ & $\mathrm{X}$ & $\mathrm{X}$ \\
\hline $\begin{array}{l}\text { Cultural } \\
\text { Programs }\end{array}$ & $\mathrm{X}$ & $\mathrm{X}$ & $\mathrm{X}$ & $\mathrm{X}^{*}$ \\
\hline $\begin{array}{l}\text { Programs For } \\
\text { Children }\end{array}$ & $X$ & & $\mathrm{X}$ & \\
\hline
\end{tabular}

*In the case of Szatmar-Bereg Plum path.

Source: Author's development

The comparison between the two Hungarian plum paths and international examples reveals that they have multiple attractions to meet tourists' demands almost completely. However, as Hungarian palinka paths are young, their recognition should be enhanced even within our country. A marketing centre established on the basis of the Austrian method could be a great contribution to increasing the number of visitors.

\section{Palinka gastronomy}

Palinka is a more complex and special beverage than that of other nations. The source material is the same for all foreign products, but the maturation in barrels gives their special value and their taste is "to be read into them". In contrast, Hungaricum palinka is a distillate faithfully representing the taste and odour of numerous fruits. Its unique nature is due to the fact that it epitomises the palinka master's professionalism and philosophy of palinka. The word "palinka" should become as well-known and widespread among foreign consumers as 
the Hungarian salami or goulash.

Kopcsay $(2008$, 89. p..) summarised the relationship of palinka consumption and gastronomy as follows: "The other custom, i.e. its consumption as an aperitif before meals has become outdated. In the culture of healthy food there is no reason to consume a short, strong alcoholic drink on an empty stomach. In European countries with a developed beverage consumption culture, short drinks are never consumed before meals. It means that if traders seek to boost palinka consumption, they should identify and redefine the motivations behind it. The task is quite simple, as several countries have already addressed this problem and as a result they consume short drinks as digestives at the end of their meals..."

This hypothesis could have been valid in 2008, as from the viewpoint of marketing, quality palinka became wellknown among consumers at about that time. The author was right that the motivations behind palinka consumption must be redefined. The ideal solution is palinka gastronomy, the current trend. Palinka nor merely fulfils the aperitif or digestive roles, but it will become an integral part of meals.

The recommended method of palinka gastronomy is the so-called palinka supper where the courses are served with palinka for the guests, just like in the case of wine suppers, or the dishes can also be prepared by using palinka as an ingredient.

The simplest and most guest-oriented style is when the source materials of palinka are the same as those of the dish. This simple solution offers pleasant experiences, although it might get boring over time.

Beverages might appear to be tastier when consumed during food intake. If beverages are selected appropriately, they might improve the value of the perfectly prepared dish. However, the pleasant taste of dishes can be easily destroyed by choosing the wrong beverage. Contrary to misconceptions, beverages are not to be consumed after swallowing one or two mouthfuls of food. They can harmonise when they are in the mouth simultaneously. This might prove that they support, enhance, enrich each other, i.e. harmonise, or, on the contrary, one of them suppresses the other.

The selection of beverages with their additional taste and odour may enhance the gastronomic value of certain dishes and harmonise with them: professional matching will intensify, i.e. highlight or supplement the taste of dishes. Some examples of dishes prepared with palinka are the following:

"Potatoe cream soup made of stewed potatoes, served with roasted Mangalica ham and pear palinka

Pig kidney soup matured in grape palinka served with dumplings in marrow

Smoked Mangalica ham with lentils salad mixed with quince palinka, served with celery chips

Pork tenderloin matured in apple palinka, filled with forest mushrooms, served with chive sauce

Knuckle filled with oven-baked sour cabbage and smoked sausage topped with plum palinka served with roasted onion and potatoes

Oven baked pork spare rib topped with apple palinka, served with potatoes and bacon
Oven baked cuts filled with marrow and smoked knuckle, baked with onion and potatoes, topped with plum palinka" (Krizl, 2014)

It is important to note that if palinka is an ingredient, dishes are to be prepared in a different way than in the case of wine. As the valuable aromas of palinka can be easily lost, it will be used after heat treatment, as the final step of cooking.

Palinka may represent a new trend of using herbal extracts due to various vegetable distillates. Examples for this are beetroot, wild garlic, tomatoes, carrot, asparagus and celery distillates. The alcohol yield of vegetables is very low, therefore their prices run high; however, they add a piquant flavour to dishes.

However, the remaining ingredients in the dish are relevant, as they can soften or suppress the taste of palinka. Typical additives of this nature are black pepper, or a significant quantity of mint that can induce the same effect. If dishes are too spicy or hot, they might reduce the pleasant aroma of palinka.

Preparation technology is also crucial for certain dishes but when it comes to palinka, it takes an even more significant role. This means that the given palinka is to be selected in terms of taste sensation in the mouth and alcohol content to match the given dish perfectly and to create full harmony. For example: the consumption of Irsai Oliver grape palinka is a perfect match for goose liver pie. After this course, caramelized raisins and brioche are served. In this case, the Irsai Oliver grape palinka is almost "too much". Without raisins the match would be perfect. Raisins are too sweet whereas the liver is soft and the brioche is crispy. In this instance the ratio of taste and odour should be carefully examined. Let us suppose that the characteristic nature of the goose liver and the brioche requires spicier palinka and the spices will be harmonically balanced by the sweet raisins. Carefully prepared Aszu marc palinka of $45 \mathrm{~V} / \mathrm{V} \%$ can be the best choice for this purpose. Naturally, palinka gastronomy is subjective, but when we seek the harmony of the meal, objectivity is also needed, as much as it is possible.

Brill Palinka House has been the first in Hungary to organize a competition of dishes prepared with palinka. They called for the public to send recipes, which were prepared by the chef of the distillery and then the jury evaluated them. Brill Palinka House has been a front-runner with not merely with the palinka competition to promote palinka gastronomy, but also with the preparation of vegetable distillates. Edit Krizl, the owner of Brill Palinka House claims that vegetable distillates are exclusively added to the dishes at the end of the cooking phase to preserve aromas and to make the dishes even more intensive.

\section{SWOT analysis on the situation of palinka gastronomy and overall industry}

The SWOT analysis (shown in Table 2) is suitable tool for examined the internal and external environment of palinka gastronomy highlighting its strengths and weaknesses, clarifying the inner qualities, potentials and threats as well as external conditions. 
Table 2: SWOT analysis of palinka gastronomy and overall industry.

\begin{tabular}{|c|c|}
\hline Strengths & Weaknesses \\
\hline $\begin{array}{l}\text { - wide range of excellent } \\
\text { fruits as a base material } \\
\text { - good quality distillates } \\
\text { - palinka culture on the rise } \\
\text { like; thematic palinka path, } \\
\text { palinka competitions, } \\
\text { palinka books, palinka } \\
\text { dishes, palinka cookbook } \\
\text { - special palinka shops } \\
\text { awilable } \\
\text { - continuous innovations } \\
\text { carry out a procedure } \\
\text { - Palinka trademark, palinka } \\
\text { excellence label }\end{array}$ & $\begin{array}{l}\text { - lack of gastronomic supply } \\
\text { matching the dishes } \\
\text { - limited palinka choice at } \\
\text { restaurants } \\
\text { - too many interest } \\
\text { organizations } \\
\text { - the palinka is less known } \\
\text { abroad } \\
\text { - Community marketing } \\
\text { is weak } \\
\text { - Palinka has not uniform } \\
\text { standard evaluation } \\
\text { system }\end{array}$ \\
\hline Opportunities & Threats \\
\hline $\begin{array}{l}\text { - the scope of palinkas with } \\
\text { a protected geographical } \\
\text { indication is expanding } \\
\text { - tender opportunities } \\
\text { - access to the international } \\
\text { market } \\
\text { - increasing the number of } \\
\text { palinka paths } \\
\text { - development of gourmet } \\
\text { consumers } \\
\text { - matured and embedded } \\
\text { "agyas" palinka gain } \\
\text { ground } \\
\text { - introduction of the } \\
\text { obligation to examine the } \\
\text { product }\end{array}$ & $\begin{array}{l}\text { - } \text { disunity among } \\
\text { professionals } \\
\text { - frequent changes in the } \\
\text { regulatory environment } \\
\text { - further increase of excise } \\
\text { tax } \\
\text { - traditional fruit speci- } \\
\text { es (e.g. J onatan apple) } \\
\text { disappear } \\
\text { - illicit palinka distillation } \\
\text { and sale }\end{array}$ \\
\hline
\end{tabular}

Source: Author's development

One of the strengths to be pointed out is the Hungarian climate, which is excellent for fruit growing. Consequently, sufficient amounts of fruits with excellent nutritional values are available for palinka source materials.

The image of palinka has seen a considerable transformation in recent decades. This is reflected by the fact that today high quality and super premium quality palinka types are available that might compete with the best whisky. The culture of quality palinka consumption is on the rise; moreover, the culture of "prestige consumption" is emerging. The key issue here is not the alcohol content of the product, but the experience of its consumption.

In our days, consumers have a good understanding of the advantages of tulip glasses and the needless of palinka cooling. Sellers and customers are getting more conscious and the culture of palinka is under perceptible development. Several restaurants offers palinka dishes and palinka cookbooks are also available. (I9) Palinka competitions are organized in every part of Hungary, the most important are the Quintessence comtetition (Onga) and the Brillante (Gyula).

Layman customers might need help in their purchases that is not available in great supermarkets, whereas provided in restaurants. Nevertheless, special palinka shops can pride themselves with the widest possible product range and professional shop assistants. Such examples include the Hungarian Palinka House Shops in Budapest and in numerous towns in the countryside or Kiraly Palinkarium and Hungarikum in Gyor.

Producers and professionals continuously seek to make innovations to meet the greatest possible consumer demand. The range of palinka and distillate types is steadily growing. Palinka perfume has already been produced in Pannonhalma that lends itself to flavouring desserts. (Szucs, 2008)

Weaknesses include the fact that sometimes there is a lack of gastronomic supply recommended for palinka consumption. In addition to palinka, festivals typically focus on a single product, e.g. Budavar Palinka and Sausage Festival, Debreczen ZAMAT Palinka and Sausage Festival.

In some cases, restaurants merely have a limited mix of palinka products and even if they can offer rarities, those are manufactured by the same producer.

The production of palinka has a lot of related professional organizations. Their activities, not specified in detail, are the following: Hungarian Alcohol Industry Association and Product Council, Palinka National Council, Hungarian Palinka Order of knighthood, Palinka Guild Association, Pannon Distillers Egyesülete, Délkelet-Magyarországi Palinkafőzők Egyesülete, Kisüsti Palinkafôző́k Országos Association, Nograd County Palinka Friends Association, and three small orders of knighthood; Szabolcsi, SzatmarBeregi and Bükki. The front of palinka production is characterised by multiple and conflicting interests, unity is merely ostensible, moreover, it is nonexistent.

Opportunities include the fact that at present we have six products under EU protection and four ones bear protected designation of geographical indication at the national level. Nagykunsag plum and Nagykunsag quince palinka were placed on the list mentioned above in 2016. The opportunities offered by the protection have not yet been fully exploited in terms of awareness raising (marketing) and tasting (organoleptic tests) and the development of distribution chains.

Distilling plants and thus the sector itself should be supported by further aids and tender opportunities. The development of subcontract distilleries typically operating as micro-enterprises should be a key issue.

The owner of Agard palinka distilling plant claims that "palinka is world-famous in Hungary". This is a situation to be changed by entry to foreign markets, which can merely be achieved by state support and active marketing activities. Hungary represented itself at the TopShelf exhibition and Drinks Fair in Australia, 2014. "Palinka was regarded as a unique product by each and every visitor. They attempted to compare it to some other products but to no avail, due to 
the fact that this drink is exclusively produced from fruits." (I8) Hungarian palinka is more complex than a whisky as the "year impact", i.e. typical weather conditions in the given year exert a strong influence on the end-product. Foreign customers used to standard quality products have difficulties with understanding why products by the same distiller vary year to year. Domestication, carried out e.g. by Rezanygal, can be an example to follow.

Currently there are two palinka paths in Hungary, both of them are plum palinka themed. It would be worth creating, for example, the Szabolcs-Szatmar-Bereg County palinka path to jointly introduce three products with protected geographical indication of source, i.e. apple from Szabolcs, plum from Szatmar and sour cherry from Ujfeherto, and also the related elements of the country's valuable assets.

For the purposes of boosting palinka tourism, the development and strengthening of a civilized layer of alcohol consumers who look for quality products is a key issue.

Hungary would be able to compete internationally with its various matured (e.g. in barrels made of wood from the given fruit's tree) and "agyas" (embedded) palinka types, which are unique products. However, all this is hindered by the fact that the impact of the vintage year seems to be difficult to be accepted by consumers.

At present there is no effective testing obligation for marketed distillates, and customers may come across poor quality products, even if to a minimal extent. Although instrumental examinations are costly, their introduction may be set out and these may push up palinka prices.

Threats comprise important factors, such as disparities, egoism and disunity among the professionals of the sector. If distilling plants join their efforts, they might enter the international market with a unified (blended, i.e. prepared by the domestication of several palinka types) and if capacity problems surface, they could cooperate by subcontract distilling or using spare alcohol meters, etc. Unfortunately, the examples of this are few, as the heads of distilling plants describe the situation.

Frequent changes of the legislative environment (from 2010, authorization of home-made palinka distillation) pose a problem and meeting the requirements entails administrative burdens for enterprises.

The slow, but steady increase of taxes on alcoholic products seems to be essential to safeguard state revenues. Presumably, it will further diminish the turnover of subcontract distilleries.

My personal experience suggests that traditional fruit types, such as apple Jonatan, the characteristic source material of Szabolcs apple palinka is disappearing. This is due to related high expenses and low buying-in prices.

Being the head of a distilling plant, I can often hear that "self-made" distilleries operate in almost every settlement offering illicit distillation opportunities without the due payment of the excise tax and market their products of dubious quality. Unfortunately notaries, and not the tax office are in charge of the supervision of household distilleries and they can only warn those who break the laws for the first time.

\section{Beverages on the menu lists of restaurants}

I carried out a non-representative study by the examination of restaurant menus. Hundred restaurants were chosen at the offers of Tripadvisor in 19 country and in Budapest. It can be asserted that palinka is listed properly on the menus and it is not mixed with other alcoholic beverages. Even the most modest list offered the products of three producers and was not limited to a single brand. The widest range of choice included 37 palinka types, exceeding the list of any other menu items.

As a result of the non-representative survey, it was found that at the 100 restaurants there are 47 distilleries' products of palinka available. The ten top businesses with most products are shown in Figure 3. Figure 3. The cumulative prevalence of the products of palinka houses
in the examined restaurants

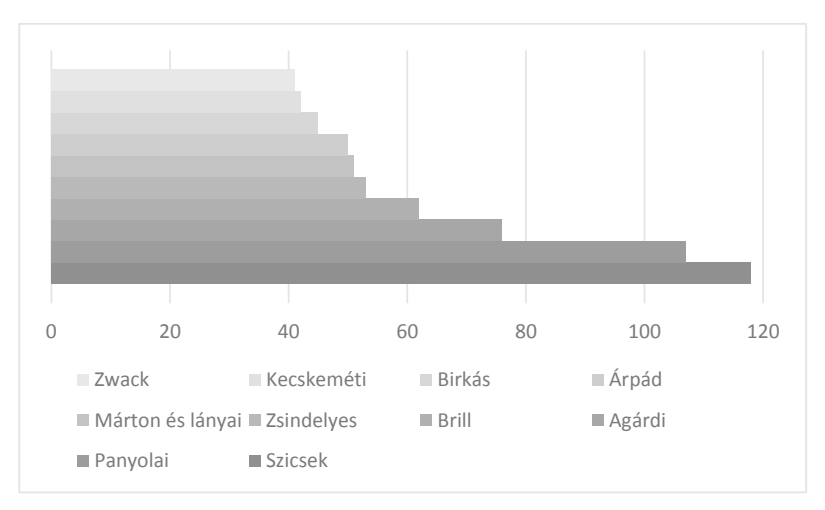

It can be concluded that the number and composition of palinka types in restaurants are steadily growing, and some products bearing protected designation of origin and geographical indication can also be found. Tasting $4 \mathrm{cl}$, depending on the selected palinka might cost from 2 to even 15 EUR (Panyola Eszencia Series) underlining the premium category of palinka.

\section{CONCLUSION, SUPPORT FOR HYPOTHESIS}

The publication of the Codex Alimentarius Hungaricus changed the definition of palinka in 2002. This move has led to changes in its market position: the product made exclusively from fruits or mash has been raised to premium rank.

Today national palinka festivals attract tens of thousands and there are regional palinka festivals almost every month. International experience shows that unique products with protected designation of origin and geographical indication can be the cornerstones of tourism for a whole region.

Active community marketing is a condition for success. In 2016 "Palinka Tour written by Jozsef Farago was published, which may serve as a guidebook for palinka tourists, motivating them to taste the products of distilleries.

My hypothesis: "The recognition of Hungaricum palinka widely known mostly in Hungary can be promoted by special means provided by tourism and gastronomy" should be further investigated. The meaning of the word „pálinka” changed in 
2002 with the appearance of the new Hungarian Food Codex. In addition the Palinka Law came into force in 2008. Thanks to these facts a number of changes have started in Hungary from that time. Whereas earlier palinka was hidden behind commercial alcoholic drinks (cherry, plum, pear and mixed "palinka") on the shelves of department stores and we could only find one or two branded products (Kecskemeti, Futyulos), now they are offered on separate shelves for customers, and restaurants rank it first on their lists of short drinks.

\section{REFERENCES}

Balazs G.: 1998. A magyar palinka. (The hungarian palinka)Aula Publisher, Bp. 23-154 p.

Balazs G.: 2008. A magyar palinka folklorja es nevkincse. (The folklore and appellations of the hungarian palinka) In: The red mail coach. 2008/spring. 23-32 p.

Balazs G.: 2012. Nagy parlat es palinkakonyv, Inter Nonprofit Ltd., Bp, 147 p.

Dlusztus I. - Soos K. 2013. A jo magyar palinka. (Good Hungarian palinka ) Our Homeland Publisher, Szeged, 238-241. p.

Farago J. (2016): Palinkatura. (Palinka tour) Alinea Publisher, Bp, 208 p.

Guth R.: Te palinkazol? (Are you drinking palinka?) In Palinka World;1 (2): 42-43.

Harcsa I. M. (2016): A magyarorszagi palinkafőzés jogszabályi változásai és hatásai. (Legislative changes and impacts of the Hungarian palinka distillation) In: ars boni, IV. 2016/No. 1. 25-42. p.

Kopcsay L. (2007) Lehet-e a palinka turisztikai vonzero Magyarorszagon? (Can the palinka be a touristical attraction in Hungary?) The Village 2007.XXII. No. 3.
Kopcsay, L. (2008) A területileg differenciált italkultúra szerepe a magyar turizmusban (The role of regionally differentiated beverage culture in Hungarian tourism. Doctoral $(\mathrm{PhD})$ dissertaion, University of Pecs Faculty of Natural Sciences Doctoral School of Geosciences. link: old.foldrajz.ttk.pte.hu/phd/phdkoord/nv/disszert/disszertacio_kopcsay_nv.pdf

Krizl E. (2014): Palinkagasztronomia eloadas. (Palinka gastronomy presentation) Corvinus University of Budapest, PowerPoint presentation.

Michalko G. (2007): Magyarorszag modern turizmusfoldrajza, (Modern tourism geography of Hungary) Dialog Campus Publisher, Bp, 288 p.

Szollosi E. (2016): Palinkaturizmus eloadas. (Palinka tourism presentation) Szent Istvan University, PowerPoint presentation, 2016. november 12

Szucs P. (2008): Amikor az ital megismeri az embert. (When palinka recognizes a man) In: Palinka World I. Year, No. 3, 26-28 p.

I1: http://gasztronomia.itthon.hu/palinkakostolo-helyek (access: 2017.03.23)

I2: http://ee.france.fr/hu/information/cognac-pineau-charentesborvideke (access: 2017.03.23)

I3: http://www.gr-marketing.at/ (access: 2017.03.23)

I4: http://www.karls.de/roevershagen.html (access: 2017.03.23)

I5: http://www.turizmusonline.hu/tt_itthon/cikk/tematikus_utak_ magyarorszagon (access: 2016.11.15)

I6: http://slideplayer.hu/slide/2162904/ (access: 2016.11.18)

I7: http://www.palinkafozes.com/hirek/20150727 turisztikaiszallashelyfejlesztes-valosult-meg-tuzseri-palinkafozdēben (access: 2016.11.18)

I8:https://businesstraveller.hu/desztinaciok/ausztraliaban-is-hodita-magyar-palinka-1120514 (access: 2017.03.23)

I9: https://palinkatona.wordpress.com/palinkas-etelek/ (access: 2018.01.23) 